\title{
Interaction Patterns of SMA/SMK Students in Buleleng Regency Based on Learning Styles in Online Learning Using LMS and Social Media
}

\author{
I Gede Sudirtha ${ }^{1, *}$ I Gede Partha Sindu ${ }^{2}$ Agus Aan Jiwa Permana ${ }^{3}$ Irwan Nur $^{4}$
}

\author{
${ }^{1}$ Family Welfare Education Study Program, Universitas Pendidikan Ganesha, Singaraja, Indonesia \\ ${ }^{2}$ Informatics Engineering Education Study Program, Universitas Pendidikan Ganesha, Singaraja, Indonesia \\ ${ }^{3}$ Informatics Management Study Program, Universitas Pendidikan Ganesha, Singaraja, Indonesia \\ ${ }^{4}$ Sociology Education Study Program, Universitas Pendidikan Ganesha, Singaraja, Indonesia \\ *Corresponding author. Email: gede.sudirtha@undiksha.ac.id
}

\begin{abstract}
The purpose of this study was to find out how the interaction patterns of high school / vocational students in Buleleng Regency were based on learning styles in online learning using LMS and social media. The method used in this research is a descriptive qualitative approach. After filling out the learning style questionnaire instrument by as many as 150 research subjects who came from high school / vocational students throughout Buleleng district, then an analysis / calculation of the score of each research subject was carried out. The results of the analysis of learning styles on SMA/SMK students in Buleleng district resulted in 54\% Visual, 36\% Auditory, 10\% Kinesthetic. Interaction patterns based on online learning styles using social media obtained results of 57\% Visual, 23\% Auditory, and $20 \%$ Kinesthetic. Based on the description of the learning outcomes between students who receive online learning using Social Media, it can be concluded that students with auditory and visual learning styles who are taught using the online learning model have a superior interaction pattern, but the Kinesthetic learning style on social media is quite good.
\end{abstract}

Keywords: Learning Management System, Social Media, Interaction Patterns.

\section{INTRODUCTION}

Online learning may be a new thing for some teachers, one solution that can be done in the learning process during the pandemic is online learning. Online learning is distance learning that requires access to internet network connectivity, one of which is by utilizing various applications on smartphones [1]. Indeed, learning activities in online networks are not the first thing for teachers in Indonesia, but many teachers are not very friendly with them, because in their daily life, teachers are generally more dominant in using faceto-face learning than online [2].

There are several obstacles faced during the online learning process, one of which is that teachers are accustomed to teaching face-to-face but during the pandemic, teachers are required to master the technology that supports the online learning process [3]. So that in this online learning process, all elements of education are asked to be able to provide learning facilities so that they remain active even though it is done without face to face directly. Another problem that arises is that parents are required to be able to guide children to learn from home and be able to replace teachers at school, so parents must take a role in achieving online learning goals and guiding children while studying at home is very important. Various problems faced by students and teachers during the online learning process during the pandemic, namely the teacher was unable to monitor the learning process directly, which resulted in the role of the teacher being replaced by parents to participate in monitoring the progress of their child's learning process [4], [5].

Such a learning system certainly makes students emotionally unstable. Learning that used to be done face-to-face with a small task intensity, has now turned into a distance learning with a lot of task intensity [6]. Other problems that arise make the emotional condition of students become unstable. Not even a few children who experience changes in character. In addition, parents who replace teachers sometimes experience many difficulties in providing an understanding of the subject matter, of course making children difficult even in conditions of online learning, not a few parents experience stress and depression[7].

Learning Management System is an application in software mode that can be used in the administration, 
also for documentation, tracking, reporting, as well as delivery of e-learning-based educational programs or training programs [8], [9]. Management is the science and art of managing the process of using human resources (HR) effectively, which is supported by other resources within an organization to achieve certain goals. The available LMS frees students to access teaching materials, and provides prerequisites for students to access teaching materials from one module to another if they have completed the previous module. LMS provides freedom for students (Self Managing), in managing their own learning to be carried out. Characteristics of LMS Feedback-Interactivity, the teaching materials contained in the LMS are arranged in a communicative language while also providing learning feedback through practice questions after each module study. LMS provides "Learning Resources" (Multimedia Learners Style) facilities that students can use to access learning resources provided by teachers in the form of videos, images, audio etc. Which can clarify student material. LMS also can be accessed flexibly at anytime and anywhere as long as there is internet access (Just in time). The characteristics of an Easy Accessibility LMS are easy to access because it only uses a browser on the student/teacher's computer and mobile phone. Characteristics of LMS which is Collaborative Learning, have discussion tool that allows direct communication at the same time and or at different times between students and teachers [10]-[12].

Social media is an online media operated by users, where users can easily participate, interact with each other, share information, and also create various content for blogs, sharing social networks, wikis, forums, and cyberspace without any boundaries in space, as well as the time, which used by the user. [13]. Blogs, social networks, and wikis are the most common forms of social media used by people around the world. Utilization of Social Media in Supporting Student Learning Process aims to find out: (1) the reasons that specific sorts of social media are used by students; and (2) ways to make the potential of social media to assist in the learning process. The results show that there are nine types of social media which are categorized into two categories, namely; Line as the main source of information and Instagram, WhatsApp, Twitter, BlackBerry, Facebook, Path, Snapchat, Youtube as a source of supplementary data to aid in the learning process. [14]. In addition, the purpose Line is utilized as the principal source of data is because, in addition to being qualified to function as a forum to acquire/explore numerous information linked to school materials and another additional information, Line can also function as a forum for sharing information and helping facilitate communication more efficiently. Furthermore, the idea for informants employing eight other types of social media as a source of supplementary data as well as information is because these eight types of social media have distinct benefits that can function as a place to obtain/search for various general information and add insight but do not function as a forum for receiving and giving as well as sharing various information. Meanwhile, informants utilize those social media to support the learning process by observing and receiving as well as giving information in the sort of pictures, words, power points, and also video tutorials. [15].

In certain lessons such as writing, learning to write in class which is continued outside the classroom through social media makes it easy for students to always improve their writing skills. The development of web services and social media can actually be used to build a cheap and efficient e-learning mechanism. The e-learning system is made by utilizing several existing and available web services, namely: facebook, google drive and google form. From the results of the study, it was found that $75 \%$ of the teachers who attended the training had been able to create an e-learning system for learning activities. While $25 \%$ still have difficulty in making independently [16], [17].

Learning styles represent something that students prefer in learning. There are 3 shorts of learning styles of students, namely visual, auditory and kinesthetic learning styles. Previous research concluded that student learning outcomes are influenced by student learning styles, especially if the learning environment accommodates student learning styles. Online learning realizes "ubiquitous" learning for students, so online learning supports the learning styles of students who like the learning environment according to their preferences and also supports the learning styles of students who like independent and collaborative learning.

Students who have a specific dominant learning style are more difficult to absorb learning compared to students who have a specific learning style that is less dominant. Learners with an auditory learning style like learning in the form of sound, for example learning lectures and discussions. Students with visual learning styles like learning with media in the form of writing, pictures, diagrams, and graphs and similar media. Meanwhile, students with kinesthetic learning styles like learning in the form of activities or practices [18].

Every student has differences in learning so that the learning styles they use must be different from one another. Individuals with a visual learning style tend to prefer to see what is being learned. Views will make it easier for them to understand ideas or information, than when presented in the form of explanations. Online learning methods with videos are the most effective way because students can listen anytime, anywhere, according to the suitability of their respective learning styles. This is different from direct interactive virtual learning methods, such as google meetings or zoom [19]. Based on the findings of the study, the method was considered less effective because of the crowded atmosphere. In addition, the direct virtual learning method is also hampered due to the condition of the internet signal quality of each student, all of which are not in good condition, so that it can interfere with other 
learning participants, especially for those who cannot study in crowded conditions. Inaccuracy in determining learning media according to student learning styles can reduce the ability to capture information conveyed by teachers to students.

\section{METHOD}

The method utilized in this study is a descriptive qualitative approach that aims to find out how the Interaction Pattern of High School / Vocational High School Students in Buleleng Regency Based on Learning Styles in Online Learning Using LMS and Social Media. By using this research, researchers get a complete and integrated understanding of the facts and cases of the problem. This research was conducted in Buleleng district with a sample of several high school / vocational students in Buleleng district. Data collection methods used are observation, questionnaires and also documentation.

The sort of questionnaire or questionnaire used in this study is a close questionnaire or structured questionnaire (Closed Questionnaire) is kind of questionnaire that uses a Likert scale to present alternative answers. The answer options consist of 5 answer options, namely: $1=$ unsatisfactory, $2=$ unsatisfactory, $3=$ quite satisfactory, $4=$ satisfactory, 5 $=$ very satisfied.

In this research, the analysis method used was carried out by: 1) classifying the average/medium score of student responses on the questionnaire given based on the Likert scale section, 2) looking for the percentage/rate of student answers, 3) interpreting student answers based on the percentage results. The time of this research was carried out in July-August 2021. The measuring instrument used in this study had been tested first on 50 respondents who were also included in the target sample. After an assessment of the respondent's answers, the validity (by item analysis, which is correlated the score of each item with the total score which is the number of each item score with the Product Moment correlation technique) and reliability (using the Cronbach Alpha technique) is tested. Calculations were then performed using IBM SPSS Statistics 20. Based on the results of the validity test revealed that the questionnaire about student responses to the use of online questionnaires was valid with a correlation probability value smaller than sig. 0.05 .

\section{RESULTS AND DISCUSSION}

Based on the results of the distribution of questionnaires related to the interaction patterns of high school / vocational students in Buleleng Regency based on learning styles in online learning using LMS and social media, it can be conveyed as follows.

\subsection{Interaction Patterns based on Online Learning Styles using LMS}

After filling out the learning style questionnaire instrument by as many as 150 research subjects who came from high school / vocational students throughout Buleleng district, then an analysis / calculation of the score of each research subject was carried out. The findings of the analysis of student learning types on SMA/SMK students in Buleleng district resulted in 54\% Visual, 36\% Auditory, $10 \%$ Kinesthetic. Thus, the dominant tendency of student's learning styles is the visual learning style. Complete data on the learning styles of SMA/SMK students are presented in Figure 1.

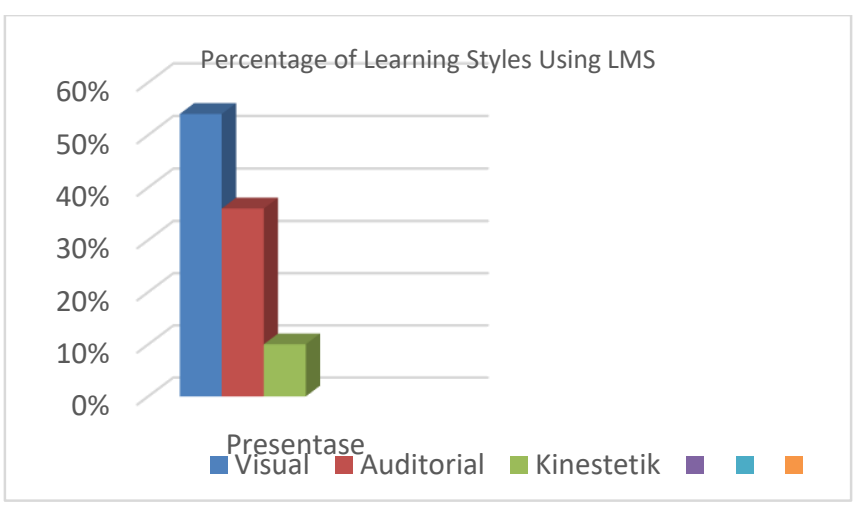

Figure 1. Percentage of Online Learning Style Using LMS.

Thus, overall, the tendency of high school/vocational high school students' learning styles in Buleleng Regency is dominated by the Visual learning style type as much as $54 \%$. Students who are very visual have the following characteristics: Organized, pays attention to everything, maintain appearance, remembers with pictures, prefers to read than be read; and Requires a comprehensive overview and objectives. Students who are highly auditory have several characteristics as follows: their attention is easily divided, speaks in a rhythmic pattern, learns by listening, moves their lips/voices while reading and dialogues internally and externally.

Based on the description of the learning outcomes between students who receive online learning using LMS, so in conclusion, students who are taught using the online learning model have a better interaction pattern than students who are taught using the traditional learning model.

\subsection{Interaction Patterns based on Online Learning Styles using Social Media}

Based on filling out the learning style questionnaire instrument by 150 research subjects to determine interaction patterns based on online learning styles using social media, the results obtained were $57 \%$ Visual, $23 \%$ Auditorial, and $20 \%$ Kinesthetic. Thus, the dominant tendency of students' learning styles is the 
visual learning style. Complete data on the learning styles of SMA/SMK students are presented in Figure 2.

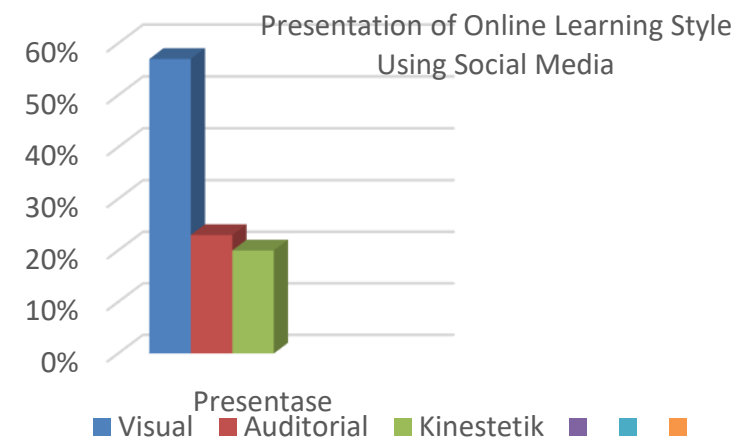

Figure 2. Presentation of Online Learning Style Using Social Media.

Based on the description of the learning outcomes between students who receive online learning using Social Media, so in conclusion, students who have auditory and also visual learning styles, and those students are taught using online learning models have superior interaction patterns, but the Kinesthetic learning style on social media is quite good. This is because social media is able to attract students' interest to follow the music movement or learning videos that are followed.

The learning process is a process of delivering information, knowledge, formal and informal information that often occurs around us. The learning process is a condition of the individual's capacity to know more. Through social media, knowledge and the learning process no longer only focuses on the accumulation of previous individual knowledge. Regardless of whether it is good or bad, utilizing the media as a tool/platform in their process of learning, it is clear that social media applications and tools have succeeded in providing a new challenge concept in the formation of formal education that already exists today.

Learning styles represent something that students prefer in learning. There are 3 kinds of student learning styles, specifically visual, auditory, and kinesthetic learning styles. Previous research concluded that student learning outcomes are influenced by student learning styles, especially if the learning environment accommodates student learning styles.

E-learning realizes "ubiquitous" learning for students, so that online learning supports the learning style of students who like the learning environment according to their preferences and also supports the learning styles of students who like independent and collaborative learning [2], [19]. Students who have a specific dominant style of learning are more difficult to absorb learning than students who have a specific learning style that is less dominant. Students with auditory learning styles like learning in the form of sound, for example learning lectures and discussions. Students with visual learning styles like learning with media in the form of writing, pictures, diagrams, and graphics and similar media. Meanwhile, students with a kinesthetic learning style like learning in the form of activities or practices. Based on the explanation related to learning styles, it can be seen that student learning styles affect students' interaction patterns and learning.

The application of social media as a learning tool/platform has established a classical theory of social learning theory. This kind of theory states that the social process of learning concentrates on how an individual studies by making another individual the subject of their study. [18]. This learning process has been supported by digital media, such as how someone learns to cook fish by watching videos of other people frying fish. In addition to learning about a simple behavior regarding one's expertise, in social media it can also be found how an individual learns and begins to think about the consequences that will arise from the behavior carried out by the subject of study. Social media in its continuation not only teaches how a communication and information technology has an impact, but also teaches how a communication technology is absorbed and adopted. The use of social media is now happening in the process of distance education (e-learning) where the teaching and learning process is no longer limited to classrooms, distance, and time.

\section{CONCLUSION}

Interaction Patterns of High School / Vocational High School Students in Buleleng Regency Based on Learning Styles in Online Learning Using LMS and Social Media. In this research, the method utilized is a descriptive qualitative approach. After filling out the learning style questionnaire instrument by as many as 150 research subjects who came from high school / vocational students throughout Buleleng district, then an analysis / calculation of the score of each research subject was carried out. The results of the analysis of learning styles on SMA/SMK students in Buleleng district resulted in 54\% Visual, 36\% Auditorial, $10 \%$. Kinesthetic. Interaction patterns based on online learning styles using social media obtained results of 57\% Visual, 23\% Auditory, and 20\% Kinesthetic. Based on the description of the learning outcomes between students who receive online learning using Social Media, so in conclusion, students with auditory and visual styles of learning are taught utilizing online learning models have a superior interaction pattern, but the Kinesthetic learning style on social media is quite good. Further research needs to discuss the effect of student interaction patterns on the learning environment and Self Efficacy in online learning using LMS and Social Media.

\section{REFERENCES}

[1] A. Anggrawan, "Analisis Deskriptif Hasil Belajar Pembelajaran Tatap Muka dan Pembelajaran Online Menurut Gaya Belajar 
Mahasiswa," J. Manajemen, Tek. Inform. Dan Rekayasa Komput., vol. 18, no. 2, pp. 339-346, 2009, [Online]. Available: https://doi.org/10.30812/matrik.v18i2.411.

[2] S. Ermayulis, Penerapan Sistem Pembelajaran Daring dan Luring di Tengah Pandemi Covid19. Riau: STIT Al-Kifayah, 2020.

[3] A. Hamid, "Efektifitas Implementasi LMS (Learning Management System) Efront Terhadap Minat dan Hasil Belajar Pada Mata Pelajaran Pemrograman Web di SMK Negeri 8 Semarang," 2015.

[4] T. . Indriani, T. Fathoni, C. Riyana, and D. Kurikulum, "Implementasi Blended Learning Dalam Program Pendidikan Jarak Jauh Pada Jenjang Pendidikan Menengah Kejuruan," Edutcehnologia, vol. 2, no. 2, pp. 129-139, 2018.

[5] E. . Kartini, L. Mimbar, and Izrawati, "Persepsi Mahawiswa Dan Pengaruh Pola Belajar, Interaksi, dan Lingkungan Belajar Terhadap Pembelajaran Daring Masa Pandemi Covid-19," 2021.

[6] Khabiburrokhman, A. Khamid, and Y. . Ali, "Analisis Gaya BElajar Siswa Melalui Media Pembelajaran Daring di Masa Pandemi Covid19," Tapis J. Penelit. Ilm., vol. 4, no. 2, pp. 192-201, 2020.

[7] M. Limbong, S. Ali, R. Rabbani, and E. Syafitri, "Pola Interaksi Guru dan Orang Tua Dalam Mengendalikan Emosional Siswa Selama Pembelajaran Daring di MTS Islamiyah Medan," J. Pendidik. Islam, pp. 44-55, 2020, [Online]. Available: https://doi.org/10.4324/9781003120155-2.

[8] E. Meinawati and R. Baron, "Media Sosial dan Pembelajaran: Studi Efektivitas Penggunaan Facebook dalam Pembelajaran Bahasa Inggris," J. Tatsqif, vol. 17, no. 1, pp. 34-51, 2019, [Online]. Available: https://doi.org/10.20414/jtq.v17i1.679.

[9] Padmo and S. Julaeha, "Tingkat Kepedulian Dan Self Efficacy Mahasiswa Universitas Terbuka Terhadap E-Learning," J. Pendidik. Terbuka dan Jarak Jauh, vol. 8, no. 2004, pp. 40-53, 2010, [Online]. Available: http://simpen.lppm.ut.ac.id/ptjj/PTJJ Vol 8.1 maret 2007/04.padmo.pdf.

[10] E. . Putra, R. Sudiana, and A. . Pamungkas, "Pengembangan Smartphone Learning Management Sytem (S-LMS) Sebagai Media
Pembelajaran Matematika di SMA," Kreano, $J$. Mat. Kreat., vol. 11, no. 1, pp. 36-45, 2020, [Online]. Available: https://doi.org/10.15294/kreano.v11i1.21014.

[11] K. D. Putro, "Pola Interaksi Anak dan Orang Tua Selama Kebijakan Pembelajaran di Rumah," Fitrah J. Islam. Educ., vol. 1, no. 1, pp. 124-140, 2020.

[12] W. . R, A. Unde, and R. . Sadjad, "Analisis Pemanfaatan Media Sosial Dalam Menunjang Proses Pembelajaran SIswa Smun 1 Makasar," J. Ilmu Komun., vol. 2, no. 1, pp. 54-63, 2019.

[13] F. Rohmah, “Analisis Kesiapan Sekolah Terhadap Penerapan Pembelajaran Online (ELearning) di SMA Negeri 1 Kutowinangun," 2016.

[14] F. Rosyida, S. Utaya, and Budijanto, "Pengaruh Kebiasaan Belajar dan Self-Efficacy Terhadap Hasil Belajar Geografi di SMA," J. Pendidik. Geogr., vol. 2, pp. 89-100, 2016.

[15] D. Setiawan, S. Lestari, D. . Putra, and M. Azmi, "Pemanfaatan Media Sosial Untuk Membangun Sistem E-Learning di SMKN 1 Gunung Talang," J. Inov. Vokasional dan Teknol., vol. 18, no. 1, pp. 7-12, 2018.

[16] S. . Seto, L. Suryani, and M. G. . Bantas, "Analisis Efikasi Diri dan Hasil Belajar Berbasis E-Learing Pada Mahasiswa Program Studi Pendidikan Matematika," Prima Magistra J. Ilm. Kependidikan, vol. 1, no. 2, pp. 147-152, 2020, [Online]. Available: https://doi.org/10.37478/jpm.v1i2.472.

[17] I. . Suarta, "A Relation Of The Learning System, Environmental Learning, Self-Concept and Development of Student's Employability Skills," Junral Penelit. Dan Eval. Pendidik. A, no. 16, pp. 24-41, 2012, [Online]. Available: http://download.portalgaruda.org/article.php?art icle $=52258 \& \mathrm{val}=448 \&$ title $=$ HUBUNGAN SISTEM PEMBELAJARAN, LINGKUNGAN BELAJAR, KONSEP DIRI DAN PENGEMBANGAN EMPLOYABILITY SKILLS MAHASISWA.

[18] N. Tambunan and I. Siagian, "Problematika Pada Pembelajaran Daring Dan Tingkat Pencapaian Hasil Belajar Siswa Pada Materi Ajar IPS: Sebuah Studi Kasus Pembelajaran Daring Masa Pandemi Covid-19," Semin. Nas. Pendidik. IPS, no. 2, pp. 371-382, 2020.

[19] Y. Wahyudi, M. . Mubarika, and E. Firmansyah, "Implementasi E-Learning Untuk Mengembangkan Self Efficacy Siswa," 2019. 